\title{
Social Resources Mobilization for General Education Development: A Case Study for Secondary Schools in Ho Chi Minh City, Vietnam
}

\section{Thanh Dac Nguyen ${ }^{1}$, Phuong Nam Nguyen ${ }^{2,+}$}

\section{Article history}

Received: 05 April 2021

Accepted: 18 May 2021

Published: 30 June 2021

\section{Keywords}

Social resources mobilization, school development, secondary schools, Ho Chi Minh City, the South of Vietnam

\author{
${ }^{1}$ Ho Chi Minh University of Education, Vietnam; \\ ${ }^{2}$ Hanoi National University of Education, Vietnam \\ ${ }^{+}$Corresponding author •Email: phuongnn@hnue.edu.vn
}

\begin{abstract}
The mobilization of social resources for educational development in schools is considered an important demonstration of the roles and responsibilities of parents and the community for the cause of education. This paper describes the frequency and efficiency of nine categories of social resources mobilization used in secondary schools in the South of Vietnam. The research team identified the reasons for and methods by which the mobilization of social resources takes place in six secondary schools in Southern Vietnam. We combined a questionnaire, completed by 202 school teachers and school managers, with in-depth interviews, observation and document analysis. The results showed high levels of both implementation and efficiency (scale reliability Cronbach's alpha 0.93 and 0.92 ) of the mobilization of social resources, revealing a high interest in and engagement with social resources mobilization by social educational forces. Based on those results, we make a number of suggestions for improving the efficiency of this work, particularly in the South of Vietnam in reality.
\end{abstract}

\section{INTRODUCTION}

Mobilizing social resources to develop education in schools is considered to be important proof of the role and responsibility of students' parents and their community for education. The donation of resources, such as money, household goods and labor (Epstein, 2007; Crites, 2008; Leithwood, 2005), for developing educational activities in schools has been common for ages in Vietnam. Although Vietnam's national budget for education represents quite a large portion of the GDP) The budget does not provide for grass-root activities in schools in every province (Luong, 2014; Poon, 2010). According to Vietnam's Ministry of Education and Training (MOET), the state investment in education fluctuates by $20 \%$ per year (MOET, 2020). State spending on schools is often very tight, so mobilization of social resources is essential (Luong, 2014; Yoon, 2010). Mobilization of resources gathered from parents and within communities reduces the financial pressure on state budgets and schools while providing material and nonmaterial resources that are of great significance to the school development (Al-Samarrai et. al, 2019; Dang, 2020).

The government has established principles, policies and procedures for raising funds as a way to in order to encourage families and local communities to advocate for resources in accordance with the law. The government seeks to prevent the misuse of funds (MOET, 2018, 2021). In Vietnam, such resources are listed as availability of mobilization which are the equipment and facilities for teaching activities, for scientific research (MOET, 2018, 2020), for education quality measurement and school quality assurance implemented with local authority engagement in the present area (Luong, 2014; Poon, 2010).

We address three research questions: (1) What is the current state of social resource mobilization implemented in secondary schools in Ho Chi Minh City? (2) What reasons are used to explain this state? (3) How could the mobilization of social resources be improved in the education development of schools in Ho Chi Minh City in particular and Southern Vietnam in general?

2. LITERATURE REVIEW

\subsection{Concept of 'resources' and related definitions}


Such related definitions as internal efficiency, school resources have been gathered and analyzed for many years. According to Williams (1994), the concept of 'resources' developed out of the Latin phrase "resurgere" and is literally interpreted as 'again' (re) to rise (surgere), or "to rise again". "Re surgere" developed into the French word "resource" and is defined as something that can be drawn upon when needed and/or as a means to gain an advantage. Resources were viewed as something that a country, organization or individual has and can use, especially to increase wealth or provide support or comfort when needed (Hoxby, 2004). Mayor (2009) provides a more comprehensive definition. He includes land or materials found in nature, such as coal or oil, that a country can use to increase its wealth; the available money, property and skills that can be tapped when needed; personal qualities such as courage and determination that are necessary in dealing with a difficult situation; and books, films, pictures, etc., used by teachers and students in the learning process (Poon, 2010; Epstein, 2007).

In short, resources are the basic tools necessary for the performance of tasks and for the growth and development of human organizations. The constitution of a resource is determined by the uses to which it can be put. In economic terms, a resource is identified by its ability to solve problems and yield more wealth. Resources can be invisible or visible (Leithwood, 2005; Awuor, 2015). Resources are classified as being visible when they exist and can be quantified in forms such as human beings, land, money, property, books and so on. Resources are invisible when they exist in the form of skills and physical ability and can be measured only in terms of productivity and quality of work. It is difficult to determine invisible skills or abilities if tasks are not assigned to human beings. Human beings are considered a special resource (Epstein, 2007; Crites, 2008; Leithwood, 2005). Unlike physical capital, human resources cannot be used as collateral for loans. Human capital is therefore consciously created through education and training (Hoxby, 2004; Awuor, 2015; UNESCO, 2010; Al-Samarrai et al., 2019). Human resources also have the ability to produce material resources. While accepting the general definition of land as a natural resource (Awuor, 2015), the quality of land can be improved by the application of human labor and expertise. A farmer is able to produce better land by extracting weeds or adding fertilizer to improve soil balance. Similarly, in the field of education, professionals (teachers) are required for the effective manipulation of educational resources. According to Black (2003), the cost of creating human capital falls mostly on individuals or their families, philanthropic institutions or the state. Financial capital is a significant resource often assumed to be a part of physical capital; it is actually the basis for procurement, utilization, and maintenance of all types of resources (Leithwood, 2005; Dang, 2020).

Regardless of the type of activity to be performed, time is a most crucial resource. Without time management, the efficient and effective use of all resources will be impossible. Awuor (2015) acknowledged the role of time as an essential component of resources that contributes to qualities of a successful manager or of subordinate staff. Hence, Drucker (1988) refers to time as "the limiting factor for effective executives" emphasizing it as a "unique resource" which cannot be rented, hired, purchased or otherwise obtained in large amounts. He maintained that time is irreplaceable, that everything requires time and that its supply is inelastic. For him, time is a valuable resource that must be used efficiently to accomplish stated objectives or goals of an institution. Therefore, effective time management stands as a necessary tool for organizations to realize their objectives and goals.

In both private and public profit organizations, time is crucial and a leading resource for the effective running of the system (Luong, 2014; Al-Samarrai et. al, 2019; Dang, 2020). For example, the hours and amount of time that an individual works are based on an agreement between participating individuals and an organization. The status quo must be maintained in order to avoid time conflicts between the employer and the employees. If schools are regarded as an organization like this, even in the private or public sector, we should strictly consider such resources, especially invisible ones, as time, finance, communication (ideas, negotiation agreed) amongst human beings in it.

The term mobilization is mentioned in a variety of works (Epstein, 2007; Bui, 2020; Awuor, 2015). In this paper, we regard the term in relation to its impact in education and society; 'mobilization' then, refers to efforts made to maximize the use of available resources to initiate, sustain, and improve teaching and learning and in school development in particular and for local and community development in general. Resource mobilization theory attempts to explain social movements by viewing individuals as rational actors engaged in instrumental actions that use formal organizations to secure resources and foster mobilization. The success or failure of a social organization is determined by external factors affecting the flow of resources (Dang, 2020; Awour, 2015; Al-Samarrai et. al, 2019).

The concept of social resources mobilization is multi-disciplinary. In terms of natural resources, for example, it is highly appreciated as an essential factor in waste disposal, especially in big cities (Bui, et. al, 2020). In the context 
of schools and education development, social resources can be divided into three categories: monetary funding, inperson sponsorship and non-material sponsorship (MOET, 2010). Monetary funding is regarded as a sum of money in Vietnamese Dong or foreign currency, diamonds, gems, or precious metals that can be directly transferred to the educational institution or through its bank account (which is opened at the State Treasury or commercial bank by a sponsor). In-person sponsorship refers to the transfer to the educational institution of items such as books, notebooks, clothing, food, materials, equipment, teaching utensils, instruction works and other materials that meet the needs of students and their educational conditions. For the form of project construction as sponsorship, the appraisal and approval in terms of technical design and total estimates, issuance of construction permits, quality management of works, testing, handover, warranty and insurance of construction works are carried out in accordance with the current law on construction investment. Last but not the least is non-material sponsorship, in which the sponsor transfers or grants the right of the receiving organization to use, at no cost, copyrights and ownership of assets belonging to intellectual property; land use rights; or volunteer labor for educational purposes such as training, sightseeing, surveys, seminars, or consultation.

Categories of social resources can be described in different ways, but the two main streams of these resources are those that are visible and invisible. In our opinion, these social resources should be divided into grass-root activities in which way it remains the classification of social resource mobilization for education development in local areas. In this study, we examined social resources mobilization using nine types of grass-root activities based on the intended purposes of the donatied resources. These are resources mobilization supporting (1) minor teaching facilities in schools; (2) scientific research in schools; (3) educational infrastructure fixed and repaired in schools; (4) educational infrastructure newly-built for educational activities in schools; (5) staff development for teaching activities in schools; (6) staff development in scientific research and action plans in schools; (7) education quality measurement and school quality assurance; and for (8) fostering roles and accountability of supervision by social organizations and community; and (9) local community activities in educational development plans in the area. This approach is consistent with the circular by MOET (2018).

The process of resources mobilization involves four main steps (Awuor, 2015; Achola, 1988). The first step is to identify and analyze the organization's, community's or institution's needs. The second step is to identify the necessary stakeholders and potential donors or contributors and try to analyze why they should assist in or give money to a particular education activity. Third is to analyze their ability to contribute toward the achievement of the program; that is, to determine who is going to contribute, and what or how much they are going to contribute. The fourth step is to formulate a resources mobilization theme. The theme should appeal to the potential contributors' minds (the logic behind the organization's request) and hearts (the emotions in the heart of the giver). This is similar to developing themes and slogans for political campaigns.

\subsection{Description of contents in social resources mobilization in Vietnam}

In Vietnam, the mobilization of social resources can be grouped into two main content areas: (1) equipment and facilities (including repairs and maintenance) for teaching and scientific research activities (macro); and (2) education, training and scientific research activities (micro) (MOET, 2018). At the macro level, such infrastructures as grounds, multi-functioned gymnasiums, classrooms, labs, school gardens, swimming pools, restrooms, etc., are being built or repaired. Mobilization of finance, time, information or human resources are typically launched in annual students' parent meetings. At the micro level, mobilization of support for teaching facilities is normally prepared year by year, or periodically in school planning. The student facilities have been individualized due to their needs and personal characteristics. Those given out the fact that teaching/learning facilities equipment should be assigned as secondary school students and their parents' responsibility in order for the most efficiency.

\section{MATERIALS AND METHODS}

We sent our questionnaire to 202 homeroom teachers at six secondary schools in Ho Chi Minh City including: Tan Phu School (Tan Phu District); Lawrance S.Ting School (District 7); Tran Quoc Tuan Secondary School (District 7); Hai Ba Trung Secondary School (District 3); Binh Tho Secondary School (Thu Duc District); Center for Lifelong Education (District 6).

Table 1. Participant schools in the survey

\begin{tabular}{clcc}
\hline No. & \multicolumn{1}{c}{ Schools } & Quantity & Rate (\%) \\
\hline 1 & Tan Phu School (Tan Phu District) & 40 & 19.63 \\
\hline 2 & Lawrance S.Ting School (District 7) & 29 & 14.49 \\
\hline 3 & Tran Quoc Tuan Secondary School (District 7) & 28 & 14.01 \\
\hline
\end{tabular}




\begin{tabular}{clcc}
\hline 4 & Hai Ba Trung Secondary School (District 3) & 37 & 18.22 \\
\hline 5 & Binh Tho Secondary School (Thu Duc District) & 59 & 28.50 \\
\hline 6 & Center for Lifelong Education (District 6) & 9 & 5.14 \\
\hline Total & $\mathbf{2 0 2}$ & $\mathbf{1 0 0}$ \\
\hline
\end{tabular}

In addition, we sought more detailed information through interviews with 12 teachers; parents of six students and managers at each of the participating secondary schools. The interviews were designed to help us better understand how local practices factor into how schools mobilize social resources.

We also made site visits to observe the educational activities in which these secondary schools engaged in resource mobilization, parents' commitment and devotion to the mobilization process as well as the resources collected. The illustration for this which was also served for paper research mission was collected in management documentation by the school managers, and also relevantly showed for this research paper assurance in needs.

We also examined documents related to resources mobilization plans by homeroom teachers and school leaders, of parents' meetings (both scheduled in advance and unplanned); and recordings (including archives of images and videos) that demonstrate the results of mobilization activities.

\section{RESULTS AND DISCUSSION}

\subsection{Results}

The survey was conducted with the 5-level Likert scale which showed the level of implementation and efficiency of mobilization efforts:

\begin{tabular}{ccc} 
Table 2. Levels of implementation and effectiveness labeled with the average points \\
\hline Average points & Levels of implementation & Effectiveness labeled \\
\hline From $1.00-1.80$ & Never & No effectiveness \\
\hline From $1.81-2.60$ & Occasionally & Low effectiveness \\
\hline From $2.61-3.40$ & Sometimes & Moderate effectiveness \\
\hline From $3.41-4.20$ & Often & High effectiveness \\
\hline From $4.21-5.00$ & Always & Very high effectiveness \\
\hline
\end{tabular}

Table 3. Social resources mobilized to support educational activities in secondary schools in Ho Chi Minh City, Vietnam in terms of grass-root activities

\begin{tabular}{|c|c|c|c|c|c|c|c|}
\hline \multirow[b]{2}{*}{ No. } & \multirow[b]{2}{*}{ Contents } & \multicolumn{3}{|c|}{ Levels of implementation } & \multicolumn{3}{|c|}{ Levels of effectiveness } \\
\hline & & $\begin{array}{l}\text { Average } \\
\text { points }\end{array}$ & Ranking & Std. & $\begin{array}{l}\text { Average } \\
\text { points }\end{array}$ & Ranking & Std. \\
\hline 1 & $\begin{array}{l}\text { Resources mobilization supporting minor } \\
\text { teaching facilities in schools }\end{array}$ & 3.92 & 1 & 0.98 & 3.83 & 1 & 0.89 \\
\hline 2 & $\begin{array}{l}\text { Resources mobilization supporting } \\
\text { scientific research in schools }\end{array}$ & 3.57 & 6 & 1.02 & 3.50 & 9 & 0.94 \\
\hline 3 & $\begin{array}{l}\text { Resources mobilization supporting } \\
\text { educational infrastructure fixed and } \\
\text { repaired in schools }\end{array}$ & 3.71 & 3 & 1.02 & 3.66 & 3 & 0.91 \\
\hline 4 & $\begin{array}{l}\text { Resources mobilization supporting } \\
\text { educational infrastructure newly-built for } \\
\text { educational activities in schools }\end{array}$ & 3.59 & 5 & 1.12 & 3.56 & 4 & 0.95 \\
\hline 5 & $\begin{array}{l}\text { Resources mobilization supporting the } \\
\text { staff development for teaching activities in } \\
\text { schools }\end{array}$ & 3.74 & 2 & 0.97 & 3.69 & 2 & 0.86 \\
\hline 6 & $\begin{array}{l}\text { Resources mobilization supporting the } \\
\text { staff development in scientific research } \\
\text { and action plans in schools }\end{array}$ & 3.56 & 7 & 1.01 & 3.53 & 7 & 0.87 \\
\hline 7 & $\begin{array}{l}\text { Resources mobilization supporting } \\
\text { education quality measurement and school } \\
\text { quality assurance }\end{array}$ & 3.52 & 8 & 1.08 & 3.53 & 7 & 0.96 \\
\hline
\end{tabular}




\begin{tabular}{|c|c|c|c|c|c|c|c|}
\hline 8 & $\begin{array}{l}\text { Fostering roles and accountability of } \\
\text { supervision by social organizations and } \\
\text { community }\end{array}$ & 3.63 & 4 & 1.02 & 3.54 & 6 & 0.93 \\
\hline 9 & $\begin{array}{l}\text { Local community activities in educational } \\
\text { development plans in the area }\end{array}$ & 3.48 & 9 & 0.97 & 3.55 & 5 & 0.92 \\
\hline \multicolumn{2}{|c|}{ Average points } & \multicolumn{3}{|c|}{3.64} & \multicolumn{3}{|c|}{3.60} \\
\hline \multicolumn{2}{|c|}{ Scale reliability (Cronbach's alpha index) } & \multicolumn{3}{|c|}{0.93} & \multicolumn{3}{|c|}{0.92} \\
\hline
\end{tabular}

\section{Levels of implementation}

According to the survey results, the scale reliability of Cronbach's alpha reaches 0.93 , signifying high reliability. Results showed a frequent or very frequent level of implementation of social policy content areas in secondary schools in Ho Chi Minh City (the average statistical value was 3.64, or very frequent). A considerable number of social policy content areas are considered well implemented by these participant schools".

The most frequently implemented form of mobilization is to support 'minor teaching facilities in schools' (with the value 3.92). This resource is relatively easy to mobilize; our analysis of an annual school mobilization report showed that the amount and kinds of resources raised for this kind of grass-root activity year by year is higher than others and that higher attention is paid to it by the students' parents. The second-highest ranking is toward "supporting staff development for teaching activities in schools' (value: 3.74). In this category, schools have attracted many resources to promote experiential learning and career exploration. The vice principal in one school, for example, said examples of such activities include "inviting experts to share about future career trends, the requirements of a certain profession, as well as giving more conditions for them to have study tour and field trips. Experiential learning activities are educational activities in addition to teaching subjects, which are compulsory in Vietnam's general education curriculum these days. Thus, we recognize so well the importance of this kind of educational activity that we are quite concerned with gathering educational involvement and resource gathering financially and mentally" (Ms. Pham, V. N. H.).

Based on our survey, resources mobilization supporting two categories, 'staff development in scientific research and action plans in schools' (3.56) and 'education quality measurement and school quality assurance' (3.52), have not been implemented regularly. The educational managers said they found it difficult to mobilize social resources, and that it has not been of interest to the school and society. Ten school leaders who participated in interviews said that the activities of staff development in scientific research and action plans in secondary schools were not really of importance at secondary school level and that potential donors/educators/sponsors were not interested in supporting this.

The following chart shows the level of implementation across each of three categories of survey respondents:

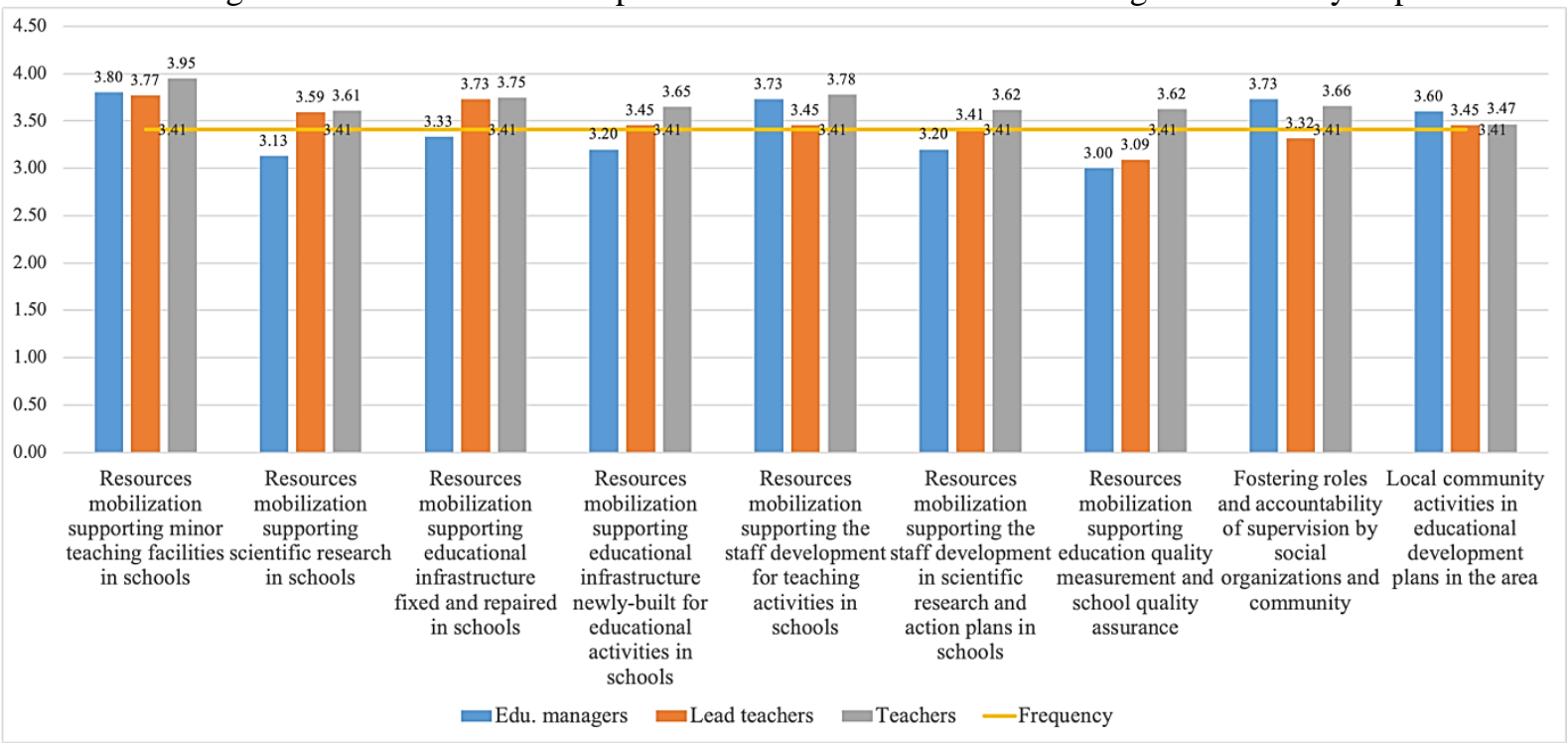

Figure 1. Social resource mobilization implemented in secondary schools in Ho Chi Minh City, Vietnam in terms of their grassroot activities 


\section{Levels of Effectiveness}

The survey, with a scale reliability of Cronbach's alpha 0.92, showed that mobilization of resources launched in secondary schools in Ho Chi Minh City, Vietnam is relatively effective, with the average statistical value reaching 3.60. A number of categories show very good results. Moreover, interviews with educational managers, lead teachers and subordinate teachers found outputs that indicated a high level of agreement about the implementation and the effectiveness of mobilization focused on educational development. Results also show high levels of agreement in a number of categories, including support for staff development for teaching activities in schools" (valued 3.69), and "educational infrastructure fixed and repaired in schools" (3.66). Document analysis (processing supervision documentation) and observation of grass-root activities in our site visits provided additional evidence to support survey findings, shown in the following chart:

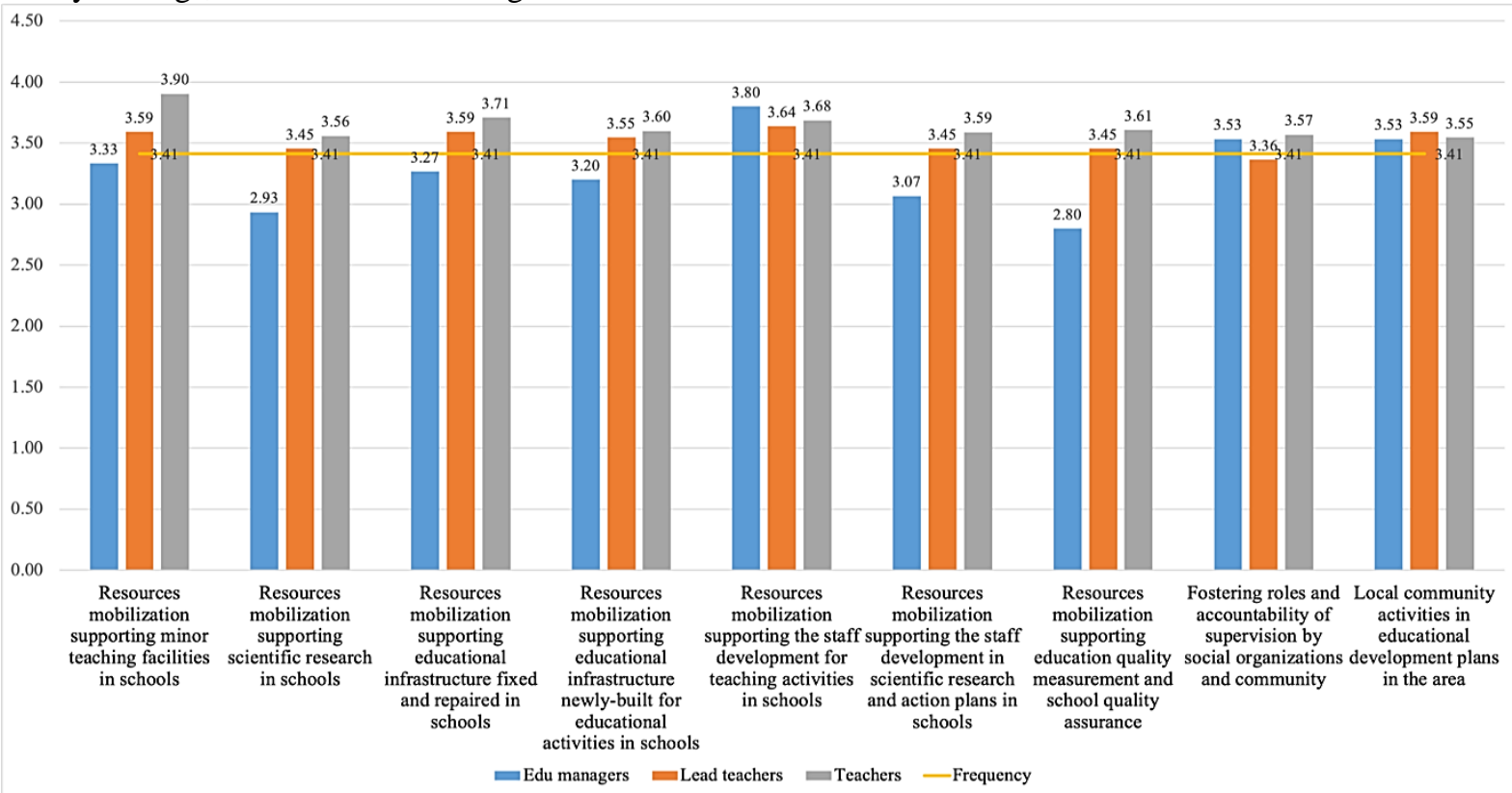

Figure 2. Survey results on effectiveness of social resource mobilization contents launched in secondary schools in Vietnam in terms of grass-root activities

One of the key findings suggests a positive correlation between levels of implementation and effectiveness in social resource mobilization for local education development. The three content areas that were ranked the highest in frequency of implementation also were the highest in terms of efficiency. These are resources mobilization supporting "minor teaching facilities in schools", "staff development for teaching activities in schools", and "educational infrastructure fixed and repaired in schools". One explanation for this may be that grass-root activities take place directly in schools, where needs and opportunities for support can be readily seen easily. These have been tightly concerned addressed with small grants and short-term financial processing involved by educational forces.

Similarly, the categories that posted low average scores on implementation also have the lowest scores in terms of efficiency. These include resources mobilization supporting "education quality measurement and school quality assurance", "staff development in scientific research and action plans in schools" and "scientific research in schools". Interviews with educator participants suggest that the main reasons for these results is that they require long-term financial planning. Moreover, the other aspects of the staff development are all mobilized such as time, teamwork and communication. Teaching and educational administration, as opposed to scientific research, have long been identified as the main targets of resources mobilization for secondary schools, not only in Ho Chi Minh City but also in Vietnam nationwide.

Researchers of social resources mobilization have focused on various aspects of the concept. Awour (2015) examined types of resources (time management, human resource management, school internal efficiency in which flow of students in schools and their performance in examinations mainly regarded). Muhangi (2019) considered three main streams of resources for secondary schools (the government, parents and donors); it mentioned resources mobilization engaged with national human capital development goals and focused on four sources of funding (the 
state, households, local communities and multinational development partners). Muhangi (2019) listed and analysed the data in the micro-term report focusing main funding streams for secondary schools, having a point in common with Awour (2015) mainly analysed resource mobilization in terms of finance. Both prioritized the economics of education. Our paper gives another perspective when learning this reflected by the grass-root activities in schools. The correlation and rankings between those items (as resource mobilization supporting minor teaching facilities in schools, resource mobilization supporting the staff development for teaching activities in schools) paralleled their points explained by their roles, frequency and impacts in the schools. Furthermore, our results provide a more detailed explanation, from our school managers and lead teachers, of the accessibility and affordability of these activities. The approach of grass-root activities when analyzing social resources mobilization provides a more educational point of view.

\subsection{Discussion}

Based on our analyses, we offer a number of suggestions for various stakeholders on the topic of social resources mobilization targeting educational development in secondary schools in the South of Vietnam.

Local authorities, Bureau of Education and Training of Ho Chi Minh City

For macro-level activities, local authorities should tightly stick to the practices and conditions in their local secondary schools, and launch guideline circulars for grass-root implementation activities. In particular, local authorities are encouraged to avoid overlap in administrative and legal regulations related to social resources mobilization. The characteristics of schools in the Southern area should be considered, overcoming difficulties in educational institutions with effectively great support provided by students' parents, social communities. Thus, it step by step meets the trend of mobilizing social resources to develop education globally.

\section{Educational managers in secondary schools in Ho Chi Minh City}

Leading educational management boards such as principals, vice principals and General Teacher Committees of each school should coordinate with educators and donors in gathering materials and other resources that could be useful to their schools. They should prioritize needs in both short-term and long-term planning. This not only proactively launches education planning for the schools and their staff but also acknowledges plans of social resources mobilization based on their school grass-root activities. The educational managers should promote both long-term and short-term planning for their schools in order to balance their educational missions with staff development and the finance budget process. Educational managers are expected to be accountable for reporting and explaining all procedures of resources mobilization. We suggest they conduct a staff survey to learn whether the staff has any other needs especially for professional development and human resources policy. The educational managers in secondary schools also play an essential as connectors. On one hand, they might be the voice of the school in every field: human, curriculum, infrastructure, classroom and facilities. On the other hand, coordinating with other external donors and educational forces. All these attempts are for educational missions done in the schools and for local education development.

Representatives of Parents Committee Board in secondary schools in Ho Chi Minh City

This organization is expected to coordinate with educational institutions in organizing for the advocacy, reception, management and use of grants. The Parents Committee Board should assign a number of representatives to the funding receiving team in secondary schools to disseminate and widely inform all parents about the purposes, meanings, principles and management of funding processing. They might also join media and/or communications teams promoted by the General Teacher Board. Last but not the least, they are expected to supervise the School Management Board in funding usage and processing to enhance efficiency of social resources mobilization in secondary schools.

\section{CONCLUSION}

Social resources mobilization has been considered as a contextualized trend, meeting the requirement of national education development targeted in the general planning report. It shows the joining hands in the educational development pathway (including visible and invisible resources, in terms of either human, finance or information), on the other hand that may on time catch up local educational development plans aligned with bottom-up planning and top-down planning. This really makes sense especially in the context of educational innovation in curriculum in Vietnam nationwide. By answering the research questions, our paper would offers a more comprehensive view from the perspective of educational sciences and gives recommendations on the behalf of educational managers and other social stakeholders. 


\section{REFERENCES}

Achola, P. P. W. (1988). Mobilizing additional funds for secondary and higher education in Kenya. Kenya Journal of Education, 4(1), 47-49.

Al-Samarrai, S., Cerdan-Infantes, P. \& Lehe, J. (2019). Mobilizing resources for education and improving spending effectiveness - Establishing realistic benchmarks based on past trends. Policy research working paper, World Bank group.

Awuor, J. O. (2015). Finance resource mobilization strategies and internal efficiency of public secondary schools in Rachuonyo South sub-city, Homabay County, Kenya. PhD in Economics of Education, University of Nairobi.

Black, S. E., Devereux, P. J. \& Savanes, K. G. (2003). Why the apple doesn't fall far: Understanding integrated transmission of human capital. NBER working paper, National Bureau of Economic Research.

Bui, T. D., Tsai, F., Tseng, M., Wu, K. J. \& Chiu, A. (2020). Effective municipal solid waste management capability under uncertainty in Vietnam: Utilizing economic efficiency and technology to foster social mobilization and environmental integrity. Journal of Cleaner Production, 259, 1-17.

Crites, V. (2008). Parent and community Involvement: A case study. The faculty of the school of Education, Library University.

Dang, T. K. P. (2020). Innovations of education socialization in Vietnam: From participation towards privatization. Educational Philosophy and Theory, 52(11), 1173-1184.

Drucker, F. (1988). People and Performance. Butterworth Heineman Ltd.

Epstein, J. L. (2007). Improving family and community involvement in secondary school. Principal Leadership. National Association of Secondary school principals.

Hoxby, C. M. (2004). Productivity in education: The quintessential upstream industry. Southern Economic Journal, 71(2), 208-231.

Leithwood, K. (2005). Education accountability: Issues and alternatives. University of Toronto.

Luong, T. V. H. (2014). Management of educational socialization involvement in senior high schools in Red River Delta area. Dissertation of Doctorate in Educational Sciences. Vietnam National Institute of Educational Sciences, Hanoi, Vietnam.

Mayor, M. (2009). Longman dictionary of contemporary English. Longman, New York.

Ministry of Education and Training (2018). Circular 16/2018/TT-BGDDT (signed on $3^{\text {rd }}$ August 2018) with its contents of funding for educational institutions in the national education system of Vietnam.

Ministry of Education and Training (2020). Workshop of finance policies in education. National Education and Human Resources Development Assembly, Hanoi.

Ministry of Education and Training (2021). Decree 24/2021/ND-CP (signed on 23rd March 2021) with Regulations on management in preschools and public general education institutions.

Muhangi, G. T. (2019). Secondary education in Uganda: Resource mobilization and efficiency. Journal of Education and Practice, 10(20), 79-90.

Poon, Y. (2010). Socialization of education in Vietnam: Lessons from international experience. People and Organization Ltd.

UNESCO (2006). Guidebook for planning education in emergencies and reconstruction. International Institute for Educational Planning.

UNESCO (2010). Mobilizing resources for international development cooperation in education: What innovative mechanisms and partnerships?. UNESCO's Bureau of Strategic Planning.

Williams, R. H. (1994). A movement dynamics and social change: Transforming fundamentalist organizations and ideology. M. E. Marty and R. S. Appleby (eds). 